臨床

\title{
A 型急性肝炎及びサルモネラ腸炎の経過観察中に
}

\section{発症した三日熱マラリアの一例}

\author{
名古屋市立東市民病院伝染科 \\ 加藤 孝治 中村 千衣 天野冨貴子 \\ 同 消化器内科 \\ 田中康之上康夫
}

(昭和57年 2 月 25 日受付)

（昭和57年 5 月 18 日受理）

Key words: hepatitis A, Malaria, P. vivax

\begin{abstract}
要旨
世界の交通網の発達により，各地の種々の風土病を観察する機会が多くなったが，診断困難な場合もある. 症例は， 22 歳白人男子学生で, 約 2 年にわたり, 欧州, 中近東, バングラディシュ,ネパール，インドを経 て来日した．彼は，インドでA型肝炎とサルモネラ腸炎に罹患し来日し入院した．この治療中に三日熱マラリ アを発症した.

インド出国時に多数の蚊に刺され，その17日後より5 日間発熱し解熱した. 35 日目に再度発熱し，48時間間 隔の定型的な熱型と, 三日熱マラリア原虫を血液像で認め, マラリアと診断した。

抗マラリア治療終了後，1週間目に行なった骨䯣穿刺では，環状体の原虫を少数認めたが，死隇し，完治寸 るものと考㝋られる.

今後国外旅行者はさらに増加し， $\mathrm{A}$ 型肝炎，マラリアを含め，各地の風土病の発生が増加すると思われる.

国外旅行者の発症に関しては，充分注意して診断する必要がある. 又治療薬剤については，種々の制限があ るが，予防投薬や，ワクチンの開発が特に望末れる.
\end{abstract}

\section{はじめに}

最近は, 発展途上国の近代化に伴う自然破壊に より，今まで知られている地方病に加光種々の新 しい疾患が発生し, 又世界交通網の発達により, これらの疾患の伝播も早くなっている。

本邦でも，昭和 20 年代までは，ょく観察された 疾患が, 社会経済的安定と, 衛生環境の向上によ りみられなくなったが, 海外青年協力隊員や, 海

別刷請求先: $\mathbf{T} 464$ 名古屋市千種区若水 1 丁目 2 番23号 名古屋市立東市民病院伝染科

加藤 孝治
外旅行者の間に 発生し，社会的問題となってお り，それぞれの国の衛生環境亡地方病を充分考慮 に入れ，予防，診断，治療を行なら必要が女る。

今回我々は世界旅行中，急性 $\mathrm{A}$ 型肝炎とサルモ ネラ腸炎の治療中に，三日熱マラリアを発症した 症例を経験したので報告する。

\section{症例}

22歳, 米国白人男子学生

主訴 : 下痢, 黄疸, 全身倦意感

既往歴：1978年 8 月バングラディシュにて腸チ フス 
家族歴：特記すべきものなし

現病歴：1977年より欧州, 中近東, バングラデ ィシュ，ネパール，インドを旅行し，原地人と同 様の生活をしていた。

1979年 3 月20日 インドにて 2 回/日の軟便， 37 $\sim 38^{\circ} \mathrm{C}$ の発熱, 全身倦总感を来たし, 発熱が軽快 した 3 月 25 日より尿色が濃くなり，黄疸に気付い た。軟便は，黄疸出現後 1 日10数回の下痢にな り，全身倦怠感，食欲不振はさらに増強した。 3 月30日来日，大阪検疫で，培便を受け，サルモネ
ラ症 (Salmonella thompson) と診断され，4月 4 日入院した。入院時下痢は 1 日 2 回の軟便に軽 快していた。

\section{入院時現症}

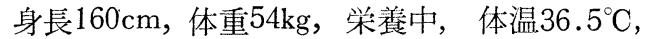
脈拍 $72 /$ 分整, 血圧 $110 / 70 \mathrm{mmHg}$, 眼球結膜 は黄 染，皮虐は黄疸色軽度乾燥，前胸部に散在性に膿 痂疹を認めた. 肝は腫大し季肋下部 2 横指軟かく 触知し，肝圧痛を認めたが，脾及び表在リンパ節 は触知しなかった。

Table 1 Laboratory data

\begin{tabular}{|c|c|c|c|c|c|}
\hline Blood chemistry & & IgA & $350 \mathrm{mg} / \mathrm{dl}$ & $\mathrm{RBC}$ & $381 \times 10^{4} / \mathrm{mm}^{3}$ \\
\hline Total bilirubin & $5.7 \mathrm{mg} / \mathrm{dl}$ & IgM & $261 \mathrm{mg} / \mathrm{dl}$ & $\mathrm{Hb}$ & $11.9 \mathrm{~g} / \mathrm{dl}$ \\
\hline Direct bilirubin & $4.3 \mathrm{mg} / \mathrm{dl}$ & IgG & $2580 \mathrm{mg} / \mathrm{dl}$ & $\mathrm{Ht}$ & $36.4 \%$ \\
\hline GOT & $568 \mathrm{KU}$ & HBsAg & $(-)$ & Pl & $51 \times 10^{4} / \mathrm{mm}^{3}$ \\
\hline GPT & $810 \mathrm{KU}$ & HBsAb & $(-)$ & Reticulocytes & $12 \%$ \\
\hline $\mathrm{LDH}$ & $441 \mathrm{IU} / 1$ & $\mathrm{HBcAb}$ & $(-)$ & & \\
\hline ALP & $47.7 \mathrm{KA}-\mathrm{U}$ & IgM-anti $\mathrm{HA} \mathrm{S} / \mathrm{N}$ & $3.4+$ & Urinalysis & \\
\hline TTT & $10.1 \mathrm{SH}-\mathrm{U}$ & & & Protein & $(-)$ \\
\hline ZTT & $18.1 \mathrm{~K}-\mathrm{U}$ & Peripheral blood & & Glucose & $(-)$ \\
\hline T.P. & $7.3 \mathrm{~g} / \mathrm{dl}$ & WBC & $7400 / \mathrm{mm}^{3}$ & Urobilinogen & $(H)$ \\
\hline Alb. & $52.0 \%$ & Eosinophils & $8 \%$ & Bilirubin & (H) \\
\hline$\alpha_{1}-\mathrm{glb}$ & $3.9 \%$ & Bonds & $3 \%$ & Sediment & \\
\hline$\alpha_{2}$-glb & $7.9 \%$ & Segs & $28 \%$ & $\mathrm{rbc}$ & $(-)$ \\
\hline$\beta$-glb & $9.7 \%$ & Lymphocyts & $55 \%$ & wbc & $1 / \mathrm{HPF}$ \\
\hline$\gamma$-glb & $26.5 \%$ & Monocyts & $6 \%$ & epithel & $1 / \mathrm{HPF}$ \\
\hline
\end{tabular}

Fig. 17Clinical course

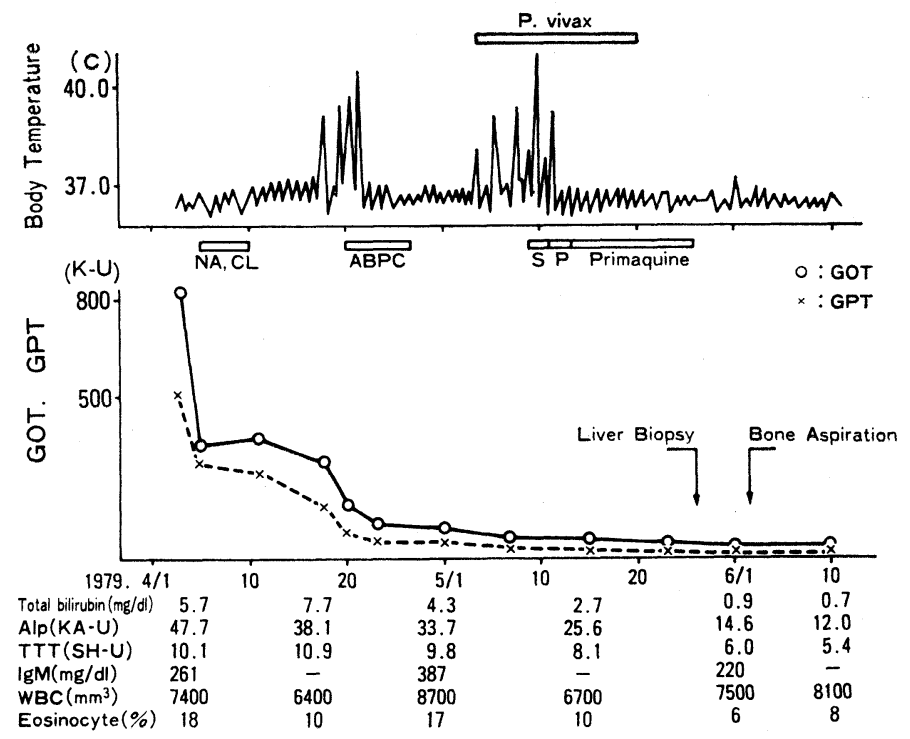


初診時検查成績は, Table 1 亿示す如くで, GIutamic oxaloacetic transaminase (GOT) $568 \mathrm{~K}$ $\mathrm{U}$, Glutamic pyruvic transaminase (GPT) $810 \mathrm{~K}$ U, Alkaliphosphatase (Alp) 47.7KA-U TTT 10.1 SH-U ZTT $18.1 \mathrm{~K}-\mathrm{U}, \operatorname{IgM} 261 \mathrm{mg} / \mathrm{dl}$ と高值を 示した.

便培看は陰性であった。

入院後経過は Fig. 1亿示す如くである.

安静・補液括よび食事療法により，全身倦点感 も徐々飞軽快し，下痢も消失した。

4 月 14 日より頭痛，不安感，筋肉痛を訴之同 16 日より何ら誘因なく，悪感についで，39〜 $40.5^{\circ} \mathrm{C}$ の発熱を来たした。発熱は弛張熱型で，血液培養 陰性で，原因不明の感染症として，ABPC 2g/日 を4月18日より投与を行ない，4月20日解熱し た. 肝機能異常は発熱後順調に正常化したが, Alp のみ 47.4KA-U から 35KA-U と依然高值を 示していた.

HA 抗体は陽性で，HAVAB-Mkit で，IgMantiHA 価3.4 と高值を示し, $\mathrm{A}$ 型肝炎と診断し $た^{11}$.

5 月 2 日より, 再度前回と同様の 訴党が出現 し, 同 4 日より $38 \sim 41^{\circ} \mathrm{C}$ までの発熱が隔日に出現 し, 強度の悪感戦慄とその後の発熱が著明にみら れた。血液検査で，好酸球増多症と共に赤血球中 に種々の形態を示す三日熱マラリア原虫が検出さ れた。原虫は環状体, 桑実期と生殖体と混在して いた。

原虫検出後 6 日目の 5 月 9 日より Sulfamethoxine (S) $500 \mathrm{mg} 2$ 日間, Pyrimethamine (P) $50 \mathrm{mg}$ 2 日間, Primaquine $15 \mathrm{mg}$ 14日間の投与を行なっ た, 発熱は, 治療開始 3 日目には解熱し, 食欲も 出現し全身状態も改善した。Alp も平常化し, 好 酸球も8\%まで低下した。

マラリア原虫は，5月20日を最後に，末梢血か らは検出出来なくなった.

肝生検組織には，マラリア原虫は認めず，急性 肝炎回復期の像を示した。しかし，6月2日に 行なった骨髄穿刺では，400倍数視野に 1 匹の割 で，環状体のマラリア原虫を認めたが，患者は退
院を希望し，6月10日退院，同12日帰国した。

\section{考 案}

アジア，アフリカなどの発展途上国では，本邦 ですでに滅亡したと考えられる様な種々の疾患 が，現在も数多く発生している. 又開発が進むに つれて, 人と野生動物との接触が増加し, マール ブルグ，ラッサなどの新しい疾病の発生もみられ る.

今回我々は，バングラディシュで腸チフスの治 療を受け，インドでA型肝炎とサルモネラ腸炎に 罹患して来日し，この治療中に三日熱マラリアを 発症した症例を経験した。

東南アジア，インド地方では， $\mathrm{A}$ 型肝炎は地方 病として存在し，10歳までに注とんどが感染し， HA 抗体をもつことが示されている ${ }^{2) ~ 4)}$. 一方米 国では，社会的経済的水準と年歯に関係して，抗 体保有率が増加している ${ }^{5}$.

患者は22歳白人学生で, 父親は大学教授といら 家庭環境で育ち，旅行中は各地の原地人に混り， ヒッピー的生活をして括り，インドで $2 \sim 3$ 月の $\mathrm{A}$ 型肝炎多発時期に罹患したもの，である。

臨床症状は, 発熱, 軟便, 全身倦㤐感で発症 し，transaminase の経過は二峰性を呈し，TTT 及び IgM 高值を示した. 又 $\operatorname{IgM}$ 分画中の $\mathrm{HA}$ 抗体陽性であった。臨床検查結果及び羅患地域に より A 型肝炎と診断したが，Alp の高值は，原虫 及び寄生虫疾患の合併を充分に注意して経過観察 する必要がある。

再度病歴を聞いた所，インド出国時，空港で多 くの蚊にさされたのを記憶して和り，来日時に は，マラリアは感染直後の潜伏期にあり ${ }^{6)} ， 4$ 月 14日に前駆症状を併い発症したものである.しか し初回の 発熱発作時には, 発熱は定型的ではな く7), 未梢血でも原虫の検出は出来なかった。 原 因不明の感染症として $\mathrm{ABPC} 2 \mathrm{~g}$ /日を投与し， 3 日後には解熱した. 肝機能異常は解熱とともに軽 快したが，5月 4 日に再度発熱し，48時間間隔に 周期性をもって発熱し，定型的な三日熱マラリア の熱型を呈し，血液像で，マラリア原虫を検出し 晾断した ${ }^{8)}$. 
抗マラリア治療薬剤は，成書に記載されている が，本邦では発売されていないのもあり ${ }^{910)}$ ， 入 手に時間がかかり，患者の苦痛を延ばすことにな る、特に熱帯熱マラリアでは，治療がおくれる々 原虫が増加し，6日以上経過すると急激に増悪す ることがあると報告されている11). 今回 Primaquine は厚生省輸入マラリア研究班より分与を受 治療を行なった。現在は外国旅行者からも手入 しすぐに治療に入れる様にしている。

不適切なマラリアの治療例では, 再発例子みら れる. 本症例では, 治療終了後 1 週目に行なった 骨髄穿刺に扣いて400倍数視野に 1 匹の割で環状 体のマラリア原虫が認められた。 この原虫が今後 死滅するのか，或は生存して再発の原因となるの か確認出来なかったが，Primaquine 投与による 充分な治療を行なって挌り，死滅し完治するもの と考光られる.

今後は治療により減少した原虫の検索を末梢血 液像と骨髄像と合わせ検索する事が必要であると 思われる. 又検索法の感度を向上させると共によ り簡便な方法の開発が望まれる。

本院では，マラリアは本症例が第 1 例目で昭和 56 年末までに 3 例観察している.

今後さらに海外との交流が増加するにつれ, 種 々の地方病の発生も増加している. 本症例からわ かる様に表面に顕われた疾病に目をらばわれてし まうと重大な見落しをすることが多々ある．従っ て海外からの帰国者, 特飞熱帯地方からの㷌国者 の発熱を診る場合には，マラリアを充分考慮に入 れて和く必要があり反省と共に報告した。

\section{まとめ}

インドにてA型肝炎とサルモネラ腸炎に罹患 し，来日した患者の経過観察中に，三日熱マラリ
アを発症した 1 例を報告した。

本論文の 要旨は, 第22回及び 第 24 回日本感染症学会 中日本地方会総会に打いて発表した。

診断及び治療について御指導いただいた岐皁大学大 友弘士教授に深謝致します。

本研究の一部は名北労働基準協会医学助成金に上。 た.

\section{文献}

1) 水野元夫他：HAVAB-M kitを使用した IgM 型 $\mathrm{HA}$ 抗体測定による $\mathrm{A}$ 型急性肝炎の早期診 断。肝臟, $21: 1400,1980$.

2) Szumness, W., et al.: The prevalence of antibody to hepatitis A antigen in various parts of the world: A pilot study. Am. J. Epideminol., 106: 312-398, 1977.

3) Wong, D.C., et al.: Prevalence of antibody to hepatitis $\mathrm{A}$ and hepatitis $\mathrm{B}$ viruses in selected populations of the south pacific. Am. J. Epideminol., 110: 227-236, 1979.

4) 佐藤 明他：ネパールにお汀る HA 抗体の年 令別分布. 肝臟, $22: 118,1981$.

5) Szumness, W., et al.: The prevalences of antibody to hepatitis $\mathrm{A}$ antigen in urban adult populations. N. Eng. J. Med., 295: 755-759, 1976.

6) Wintrobe, M.W., et al.: Harison's Principles of Internal Medicine, 6th ed. Internal Student ed. New York 1970, p. 1030-1034.

7) 阿部正和他: 新臨床内科学, 第 2 版, 医学書 院, 東京, 1976, p. 767-768.

8) 金井 泉 他: 臨床検查法提要, 改訂增補 第 25 版, 金原出版株式会社, 東京, 1970, VI 122VI 125 .

9）重松逸造他：伝染病予防必携，第 2 版 補訂版, 日本公衆衛生協会, 1979, p. 217一221.

10）海老沢功：最近のマラリア治療の現況.日本薬 剂師会誌，31：431-440，1979.

11）海老沢功他：マラリアーとくに熱带熱マラリ アの予後決定因子にっいて一。棟臨床, 38 ： 333-335, 1980. 


\title{
A Case of Malaria having Occured on Treatment for Hepatitis A and Salmonella Enteritis
}

\author{
Kouji KATOU, Chie NAKAMURA, Fukiko AMANO* \\ Yasuyuki TANAKA \& Y Yasuo UEDA** \\ *Department of Infections Division, Nagoya Higashi City General Hospital \\ **Department of Gastroenterology, Internal Medicine, Nagoya Higashi City General Hospital
}

By the progress in the world traffic condition, we observe many kinds of endemic, but occasionally find difficulty in diagnosis.

The patient was a 22-year-old white student and came to Japan after travelling through many tropic countries for 2 years.

He had been suffered from hepatitis A and Salmonella enteritis in India and entered our hospital for the treatment.

He admitted for these diseases. During his hospitalization, Malaria was developed.

He had been bit by many mosquitoes on departure from India, and after 17 day later, he had an attack of fever for 5 days.

The fever was irregular and maturation cycle of the parasite was not synchronized.

But on 35th day, synchronization occured on the second attack of fever, we found the parasites in peripheral blood and diagnosesed.

We report that travelers from tropics may be suffered from many kinds of endemic, so it is necessary to diagnosis carefully. 